\title{
Catalytic reduction of dinitrogen to ammonia at a single molybdenum center
}

Walter W. Weare, Xuliang Dai, Matthew J. Byrnes, Jia Min Chin, Richard R. Schrock ${ }^{\dagger}$, and Peter Müller

Department of Chemistry, Massachusetts Institute of Technology, Cambridge, MA 02139

Edited by Douglas C. Rees, California Institute of Technology, Pasadena, CA, and approved June 7, 2006 (received for review April 14, 2006)

Since our discovery of the catalytic reduction of dinitrogen to ammonia at a single molybdenum center, we have embarked on a variety of studies designed to further understand this complex reaction cycle. These include studies of both individual reaction steps and of ligand variations. An important step in the reaction sequence is exchange of ammonia for dinitrogen in neutral molybdenum(III) compounds. We have found that this exchange reaction is first order in dinitrogen and relatively fast (complete in $<1 \mathrm{~h}$ ) at $1 \mathrm{~atm}$ of dinitrogen. Variations of the terphenyl substituents in the triamidoamine ligand demonstrate that the original ligand is not unique in its ability to yield successful catalysts. However, complexes that contain sterically less demanding ligands fail to catalyze formation of ammonia from dinitrogen; it is proposed as a consequence of a base-catalyzed decomposition of a diazenido $(\mathrm{Mo}-\mathrm{N}=\mathrm{NH})$ intermediate.

catalysis | fixation | nitrogenase

o ne of the most fascinating catalytic reactions in biology is the reduction of dinitrogen to ammonia by various nitrogenases, the first and most studied being one whose core contains seven irons and one molybdenum (1-4). "Alternative" nitrogenases are now known, one that contains vanadium instead of molybdenum (which functions when Mo is absent and $\mathrm{V}$ is available) and another that contains only iron (which functions when both Mo and V are absent) (5-7). The FeMo nitrogenase appears to be the most efficient ( $\approx 75 \%$ in electrons), yielding approximately only one dihydrogen per dinitrogen reduced. It also has been purified and studied for decades. Its structure has been determined in x-ray studies, and that structure has elicited a great deal of discussion concerning precisely where dinitrogen is reduced (8-11). Although a huge effort to understand how dinitrogen is reduced by various nitrogenases has been made over a period of $>40$ years, definitive conclusions concerning the site and mechanism of dinitrogen reduction in nitrogenase(s) remain elusive (12).

Two reports of the catalytic reduction of dinitrogen to ammonia with protons and electrons at room temperature and pressure have been published. The first is one in which dinitrogen is reduced to a mixture of hydrazine and ammonia $(\approx 10: 1)(13)$. Molybdenum is required, and dinitrogen reduction is catalytic with respect to molybdenum. The reaction is run in methanol in the presence of magnesium hydroxide and a strong reducing agent such as sodium amalgam. Few details concerning the mechanism of this reaction have been established. The second was reported by our group in 2003 (14). The catalysts are Mo complexes that contain the $\left[\left(\mathrm{HIPTNCH}_{2} \mathrm{CH}_{2}\right)_{3} \mathrm{~N}\right]^{3-}\left(\left[\mathrm{HIPTN} \mathrm{N}_{3} \mathrm{~N}\right]^{3-}\right)$ ligand, where HIPT is 3,5-(2,4,6-i- $\left.\mathrm{Pr}_{3} \mathrm{C}_{6} \mathrm{H}_{2}\right)_{2} \mathrm{C}_{6} \mathrm{H}_{3}$, or hexaisopropylterphenyl; an example, $\left[\mathrm{HIPTN}_{3} \mathrm{~N}\right] \mathrm{MoN}_{2}$, is shown in Fig. 1 (15-17). The $\left[\mathrm{HIPTN}{ }_{3} \mathrm{~N}\right]^{3-}$ ligand was designed to prevent any bimetallic reactions (aside from electron transfer), maximize steric protection of a metal coordination site in a monometallic species, and provide increased solubility of intermediates in nonpolar solvents. Eight of the proposed intermediates in a hypothetical "Chatt-like" reduction of dinitrogen (Fig. 2) have been isolated and characterized (Mo is $\left.\left[\mathrm{HIPTN}{ }_{3} \mathrm{~N}\right] \mathrm{Mo}\right)$. These intermediates include paramagnetic $\mathbf{M o N} \mathbf{N}_{2}$ (1; Fig. 1), diamagnetic $\left[\mathrm{MoN}_{2}\right]^{-}$(2), diamagnetic $\mathrm{Mo}-\mathrm{N}=\mathrm{N}-\mathrm{H}$ (3), diamagnetic $\left\{\mathrm{Mo}=\mathrm{N}-\mathrm{NH}_{2}\right\} \mathrm{BAr}_{4}^{\prime}\left(4 ; \mathrm{Ar}^{\prime}=3,5-\left(\mathrm{CF}_{3}\right)_{2} \mathrm{C}_{6} \mathrm{H}_{3}\right)$,

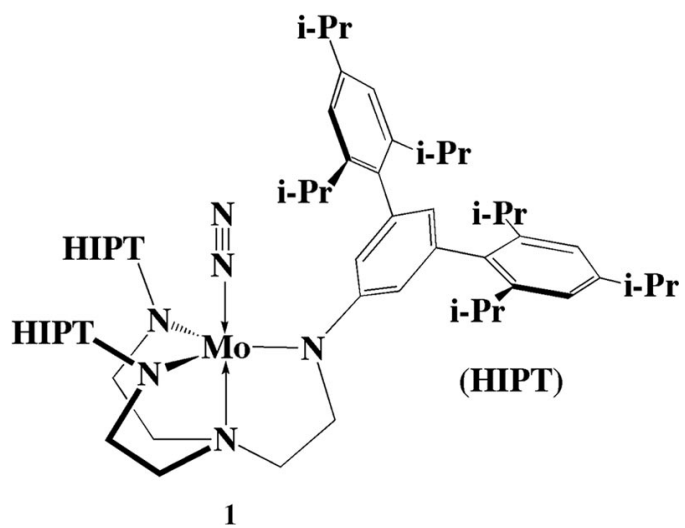

Fig. 1. Drawing of $\left[\mathrm{HIPTN} \mathrm{N}_{3} \mathrm{~N}\right] \mathrm{MoN} \mathrm{N}_{2}=\mathrm{MoN}_{2}$.

diamagnetic $\mathbf{M o} \equiv \mathrm{N}(7)$, diamagnetic $\{\mathbf{M o}=\mathrm{NH}\} \mathrm{BAr}_{4}^{\prime}(\mathbf{8})$, paramagnetic $\left\{\mathbf{M o}\left(\mathrm{NH}_{3}\right)\right\} \mathrm{BAr}_{4}^{\prime}(\mathbf{1 2})$, and paramagnetic $\mathrm{Mo}\left(\mathrm{NH}_{3}\right)(\mathbf{1 3})$. All are extremely sensitive to oxygen with the exception of 7 .

Dinitrogen is reduced catalytically in heptane with $[2,6$ lutidinium] $\mathrm{BAr}_{4}^{\prime}$ as the proton source and decamethylchromocene as the electron source in the presence of one of the complexes that is believed to be part of the catalytic cycle (14). Catalytic runs by several researchers with several different Mo derivatives (usually $\mathbf{1}$, 3,7 , or 12) reveal that a total of 7-8 equivalents (equiv) of ammonia are formed out of $\approx 12$ possible (the number possible depending on the Mo derivative used), which suggests an efficiency of $\approx 65 \%$ based on the reducing equiv available. The efficiency of formation of ammonia from the gaseous dinitrogen that is present is $55-60 \%$.

Ongoing studies of the catalytic reduction have begun to reveal why it succeeds and when, and increasingly why, it fails. In this work, we report some of the latest results concerning the parent catalytic system and contrast those with investigations that involve a "hybrid" system in which one of the three HIPT groups in the ligand has been replaced with a $3,5-\left(\mathrm{CF}_{3}\right)_{2} \mathrm{C}_{6} \mathrm{H}_{3}$ group.

\section{Results and Discussion}

What We Know About the Parent Dinitrogen Complex, [HIPTN ${ }_{3} \mathrm{~N} \mathrm{MoN}_{2}$. The synthesis of $\mathbf{M o N}_{2}$ begins with reduction of $\mathrm{MoCl}$ with magnesium to yield $\left\{\mathrm{MoN}_{2}\right\}^{-}$. Several salts of this anion have been prepared, including a $\left[n-\mathrm{Bu}_{4} \mathrm{~N}\right]^{+}$salt. In salts that contain an alkali metal or magnesium, the metal to varying degrees is bound to the $\beta$ nitrogen and to the central aryl ring in the HIPT group,

Author contributions: W.W.W., X.D., M.J.B., J.M.C., and R.R.S. designed research; W.W.W., X.D., M.J.B., J.M.C., and P.M. performed research; W.W.W., X.D., M.J.B., and J.M.C. contributed new reagents/analytic tools; W.W.W., X.D., M.J.B., J.M.C., R.R.S., and P.M. analyzed data; and W.W.W. and R.R.S. wrote the paper.

The authors declare no conflict of interest.

This article is a PNAS direct submission.

Abbreviations: $\mathrm{Ar}^{\prime}, 3,5-\left(\mathrm{CF}_{3}\right)_{2} \mathrm{C}_{6} \mathrm{H}_{3} ; \mathrm{CV}$, cyclic voltammogram; equiv, equivalent(s); HIPT, 3,5-(2,4,6-i- $\left.\mathrm{Pr}_{3} \mathrm{C}_{6} \mathrm{H}_{2}\right)_{2} \mathrm{C}_{6} \mathrm{H}_{3}$ (hexaisopropylterphenyl); HTBT, hexa-t-butylterphenyl; 2,6-Lut, 2,6-lutidine.

†To whom correspondence should be addressed. E-mail: rrs@mit.edu.

() 2006 by The National Academy of Sciences of the USA 


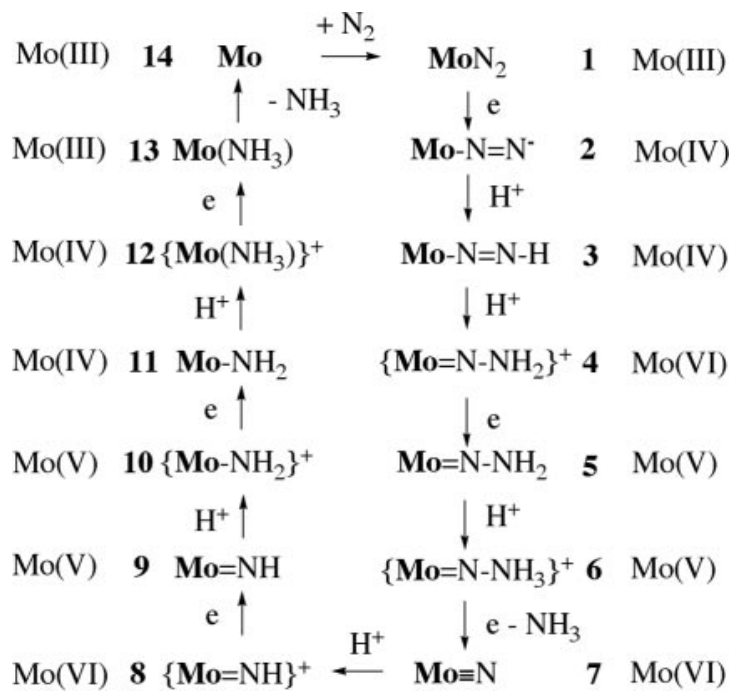

Fig. 2. Proposed intermediates in the reduction of dinitrogen at a $\left[\mathrm{HIPTN}_{3} \mathrm{~N}\right.$ ]Mo (Mo) center through the stepwise addition of protons and electrons.

depending on the metal cation and its degree of solvation by, e.g., THF. It is believed that $\{\mathbf{M o C l}\}^{-}$is formed upon reduction of $\mathrm{MoCl}$ and that dinitrogen then attacks this species to give chloride ion and $\mathbf{M o N}_{2}$. [Loss of chloride first to yield Mo, the "naked" species (14 in Fig. 2), is an alternative that now appears to be less likely, as we will see later.] One electron oxidation of $\left\{\mathrm{MoN}_{2}\right\}^{-}$ derivatives with zinc chloride produces $\mathbf{M o N}_{2}$ in good yield. It is proposed that when $\mathbf{M o N}_{2}$ is formed upon reduction of $\mathrm{MoCl}$, it is readily reduced to $\left\{\mathbf{M o N}_{2}\right\}^{-}$under the reaction conditions. $\operatorname{MgBr}(\mathrm{THF})_{3}\left\{\mathbf{M o N}_{2}\right\}$ and $\left\{\mathrm{Mg}(\mathrm{dme})_{3}\right\}\left\{\mathbf{M o N}_{2}\right\}_{2}$ have been characterized structurally (16). The dinitrogen complex is reduced (in $\left.\mathrm{PhF} / 0.1 \mathrm{M}\left[\mathrm{Bu}_{4} \mathrm{~N}\right] \mathrm{BAr}{ }_{4}^{\prime}\right)$ to $\left\{\mathrm{MoN}_{2}\right\}^{-}$reversibly at $-2.11 \mathrm{~V}$ and is oxidized reversibly at $-0.66 \mathrm{~V}$. The $\mathrm{MoN}_{2}{ }^{+/ 0}$ potential in $\mathrm{PhF}$ $(-0.66 \mathrm{~V})$ is nearly $1 \mathrm{~V}$ higher than the $\mathrm{Mo}\left(\mathrm{NH}_{3}\right)^{+/ 0}$ redox couple $(-1.63 \mathrm{~V})$ in fluorobenzene. Several relevant potentials are collected in Table 1.

A sample of $\mathbf{M o}^{15} \mathrm{~N}_{2}$ in $\mathrm{C}_{6} \mathrm{D}_{6}$ (the ratio of ${ }^{15} \mathrm{~N}_{2} /{ }^{14} \mathrm{~N}_{2}$ was 92:8) was oxidized by $\mathrm{FeCp}_{2} \mathrm{BAr}_{4}^{\prime}$ to $\left\{\mathrm{Mo}^{15} \mathrm{~N}_{2}\right\}^{+}$under ${ }^{14} \mathrm{~N}_{2}$. After $15 \mathrm{~min}$ the cation was then reduced with CoCp $\mathrm{p}_{2}^{*}$ to yield a mixture of $\mathbf{M o}^{15} \mathrm{~N}_{2}$ and $\mathrm{Mo}^{14} \mathrm{~N}_{2}$ in a ratio of 18:82, according to IR spectra. Therefore, ${ }^{15} \mathrm{~N}_{2}$ must be replaced by ${ }^{14} \mathrm{~N}_{2}$ in $\left\{\mathbf{M o}^{15} \mathrm{~N}_{2}\right\}^{+}$to a significant degree in a matter of minutes. The dinitrogen stretching mode in $\left\{\mathbf{M o N}_{2}\right\}^{+}$ in the IR spectrum in solution was found at $2,255 \mathrm{~cm}^{-1}$ in heptane. This result should be compared with a $\nu_{\mathrm{NN}}=1,990 \mathrm{~cm}^{-1}$ for $\mathbf{M o N} \mathbf{N}_{2}$ and $1,855 \mathrm{~cm}^{-1}$ for $\left\{\mathbf{M o N}_{2}\right\}^{-}$as the tetrabutylammonium salt. We believe that $2,255 \mathrm{~cm}^{-1}$ is the highest known value for dinitrogen

Table 1. Electrochemical data obtained for various compounds referenced to $\mathrm{Cp}_{2} \mathrm{Fe}^{+/ 0}$

\begin{tabular}{|c|c|c|}
\hline Redox couple & $E_{1 / 2}$ in $\mathrm{THF}^{\dagger}$ & $E_{1 / 2}$ in $\mathrm{PhF}^{\ddagger}$ \\
\hline$\left[\left(\mathrm{HIPTN}_{3} \mathrm{~N}\right) \mathrm{MoN}_{2}\right]^{0 /-}$ & -1.81 & -2.01 \\
\hline$\left[\left(\mathrm{HIPTN}_{3} \mathrm{~N}\right) \mathrm{Mo}\left(\mathrm{NH}_{3}\right)\right]^{+/ 0}$ & -1.51 & -1.63 \\
\hline$\left[\left(\mathrm{HIPTN}_{3} \mathrm{~N}\right) \mathrm{MoN}_{2}\right]^{+/ 0}$ & $-0.42\left(I_{\mathrm{pa}}\right)$ & -0.66 \\
\hline $\mathrm{Cp}_{2} \mathrm{Co}^{+/ 0}$ & -1.33 & -1.33 \\
\hline $\mathrm{Cp}_{2} * \mathrm{Cr}^{+/ 0}$ & -1.47 & -1.63 \\
\hline $\mathrm{Cp}_{2} * \mathrm{Co}^{+/ 0}$ & -1.84 & -2.01 \\
\hline
\end{tabular}

Data were taken in part from ref. 20. CV at 1.6- $\mathrm{mm}$ Pt working electrode or 3.0-mm glassy carbon working electrode at $22^{\circ} \mathrm{C}$. CV scan rates were 10-200 $\mathrm{mV} / \mathrm{s}$.

${ }^{\dagger} 0.4 \mathrm{M}\left[\mathrm{Bu}_{4} \mathrm{~N}\right] \mathrm{PF}_{6}$ in THF.

${ }_{0}^{\ddagger} 0.1 \mathrm{M}\left[\mathrm{Bu}_{4} \mathrm{~N}\right] \mathrm{BAr}_{4}^{\prime}$ in $\mathrm{PhF}$.

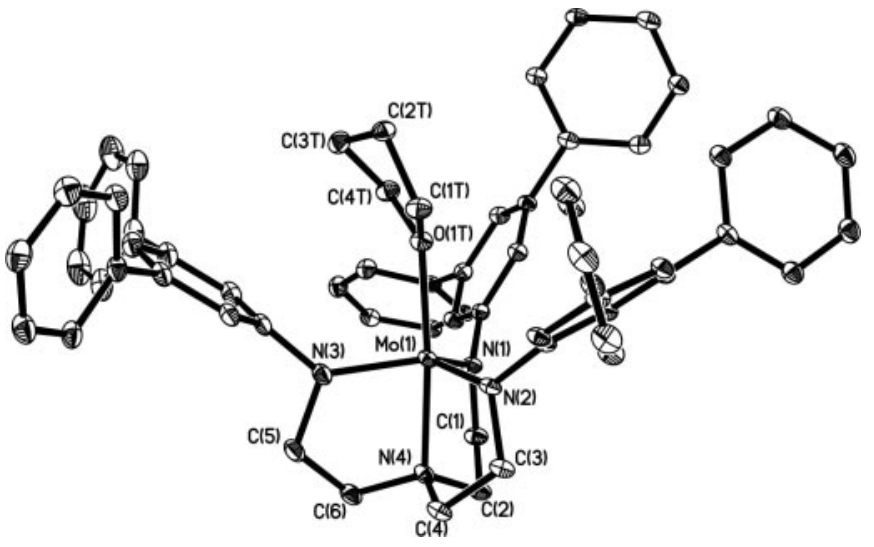

Fig. 3. Thermal ellipsoid drawing of the structure of $\{\mathrm{Mo}(\mathrm{THF})\} \mathrm{BPh}_{4}$. (Hydrogen atoms, isopropyl groups, solvents of crystallization, and tetraphenylborate ion are not shown.)

bound end on to a transition metal (18) $¥$ It should be compared with $\nu_{\mathrm{NN}}$ for free dinitrogen in the Raman spectrum at $2,331 \mathrm{~cm}^{-1}$. The reduction of $\nu_{\mathrm{NN}}$ by only $76 \mathrm{~cm}^{-1}$ in $\left\{\mathbf{M o N}_{2}\right\}^{+}$from the value for free dinitrogen suggests that $\mathrm{N}_{2}$ is very weakly bound to the metal. Note the $400-\mathrm{cm}^{-1}$ difference between $\nu_{\mathrm{NN}}$ in $\left\{\mathbf{M o N}_{2}\right\}^{-}$and $\left\{\mathrm{MoN}_{2}\right\}^{+}$. We could find no other example in the literature of $\nu_{\mathrm{NN}}$ values in three compounds (anionic, neutral, and cationic) that are prepared by removing one electron sequentially. We can view the electrons as coming from the metal, i.e., $\mathrm{Mo}(\mathrm{II})$ in $\left\{\mathrm{MoN}_{2}\right\}^{-}$is oxidized to $\mathrm{Mo}(\mathrm{III})$ in $\mathbf{M o N}_{2}$ and then to $\mathrm{Mo}(\mathrm{IV})$ in $\left\{\mathrm{MoN}_{2}\right\}^{+}$. However, the oxidation state of Mo in $\left\{\mathrm{MoN}_{2}\right\}^{-}$also could be viewed as $\mathrm{Mo}(\mathrm{IV})$, i.e., $\left\{\mathrm{MoN}_{2}\right\}^{-}$is a deprotonated $\mathrm{Mo}(\mathrm{IV})$ diazenido (Mo-N $=\mathrm{NH}$ ) complex.

Oxidation of $\mathbf{M o N}_{2}$ with $\mathrm{AgBPh}_{4}$ in THF resulted in the formation of an orange compound, which was identified as cationic, paramagnetic $\left\{\left[\mathrm{HIPTN} \mathrm{H}_{3} \mathrm{~N}\right] \mathrm{Mo}(\mathrm{THF})\right\} \mathrm{BPh}_{4}$ through a singlecrystal x-ray diffraction study. The structure shown in Fig. 3 reveals that the THF is bound to the metal along the $z$ axis with Mo$\mathrm{O}(1 \mathrm{~T})=2.1811(18) \AA$ and $\mathrm{N}(4)-\mathrm{Mo}-\mathrm{O}(1 \mathrm{~T})=173.97(7)^{\circ}$. The Mo-O distance is approximately the same as the Mo-N(4) distance [2.141(2) A]. It should be noted that in $\{\mathbf{M o}(2,6-\mathrm{Lut})\} \mathrm{BPh}_{4}(17)$ (where 2,6-Lut is 2,6-lutidine), the 2,6-lutidine is bound "off-axis" to a significant degree $\left(\mathrm{N}_{\text {amine }}-\mathrm{Mo}-\mathrm{N}_{\text {lut }}=157^{\circ}\right)$ in a "slot" created by two of the HIPT groups. The THF ligand is considerably less sterically demanding and therefore is bound strictly trans to the amine nitrogen donor. All structural information can be found in the supporting information, which is published on the PNAS web site.

Reduction of $\{\mathbf{M o}(2,6-$ Lut $)\} \mathrm{BPh}_{4}$ with $\mathrm{CrCp}_{2}^{*}$ under dinitrogen in $\mathrm{C}_{6} \mathrm{D}_{6}$ has been observed to yield $\mathbf{M o N}_{2}$ and lutidine upon mixing (17). Examination of the cyclic voltammogram (CV) of $\{\mathbf{M o}(\mathrm{THF})\} \mathrm{BPh}_{4}$ (Fig. 4) reveals that reduction of $\{\mathbf{M o}(\mathrm{THF})\}^{+}$to $\mathbf{M o}(\mathrm{THF})$ yields $\mathbf{M o N}_{2}$ in a few seconds since the complete $\mathbf{M o N}_{2}$ to $\left\{\mathbf{M o N}_{2}\right\}^{-}$couple is observed; reoxidation of Mo(THF) to $\{\mathbf{M o}(\mathrm{THF})\}^{+}$is not observed on the reverse sweep, only the wave for oxidation of $\mathbf{M o N}_{2}$ to $\left\{\mathbf{M o N}_{2}\right\}^{+}$. Therefore, it appears that dinitrogen readily replaces THF in Mo(THF), and apparently also in Mo(2,6-Lut), on the basis of the qualitative observations noted above. The orders in dinitrogen in these reactions have not been determined, but on the basis of similar reactions that involve interconversion of $\mathbf{M o N}_{2}$ and $\mathbf{M o}\left(\mathrm{NH}_{3}\right)$ and reactions involving conversion of $\mathbf{M o}^{15} \mathrm{~N}_{2}$ into $\mathbf{M o}^{14} \mathrm{~N}_{2}$ under ${ }^{14} \mathrm{~N}_{2}$ (see below for both), it seems likely that

†The highest dinitrogen stretch we have found, $2,197 \mathrm{~cm}^{-1}$ in Nujol, is in a bis(imino)pyridine $\mathrm{Co}(\mathrm{I})$ cationic complex. 


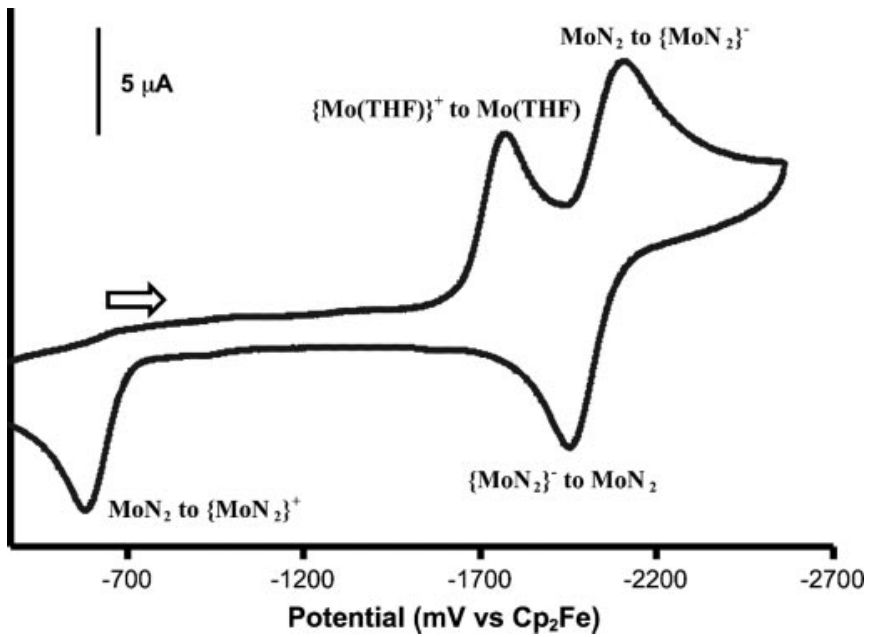

Fig. 4. $\mathrm{CV}$ of $\{\mathrm{Mo}(\mathrm{THF})\} \mathrm{BPh}_{4}$ in $0.1 \mathrm{M}\left[n-\mathrm{Bu}_{4} \mathrm{~N}\right] \mathrm{BAr}{ }_{4}^{\prime} / \mathrm{PhF}$ at a scan rate of 100 $\mathrm{mV} \cdot \mathrm{s}^{-1}$ at a glassy carbon electrode.

replacement of $\mathrm{L}$ (a $\sigma$ donor) in $\mathrm{Mo}(\mathrm{L})$ by dinitrogen is first order in dinitrogen, i.e., the intermediate is not the naked species, Mo, but a six-coordinate species, Mo $\left(\mathrm{N}_{2}\right)(\mathrm{L})$. Sixcoordinate distorted octahedral species are known in TMS- or $\mathrm{C}_{6} \mathrm{~F}_{5}$-substituted triamidoamine $\mathrm{Mo}$ or $\mathrm{W}$ complexes when strongly binding ligands are present (CO or isonitriles) (19). A crystallographically characterized example is $\left\{\left[\left(\mathrm{C}_{6} \mathrm{~F}_{5} \mathrm{NCH}_{2} \mathrm{CH}_{2}\right)_{3} \mathrm{~N}\right] \mathrm{W}(\mathrm{CO})_{2}\right\} \mathrm{Na}(\mathrm{THF})_{3}$ (19). However, stable six-coordinate species have not yet been observed in $\left[\mathrm{HIPTN}{ }_{3} \mathrm{~N}\right] \mathrm{Mo}$ systems. If we assume that the conversion of $\mathbf{M o}(\mathrm{THF})$ into $\mathbf{M o N}_{2}$ is $95 \%$ complete in $3 \mathrm{~s}$, that the reaction is in fact a displacement of THF by dinitrogen (see below), and finally that the concentration of dinitrogen in solution is $0.04 \mathrm{M}$ at $1 \mathrm{~atm}$ (see supporting information), then the bimolecular rate constant for conversion of $\mathbf{M o}\left(\mathrm{THF}\right.$ ) into $\mathbf{M o N}_{2}$ is $25 \mathrm{M}^{-1} \cdot \mathrm{s}^{-1}$ at $22^{\circ} \mathrm{C}$.

Replacement of ${ }^{15} \mathrm{~N}_{2}$ in $\mathbf{M o}^{15} \mathrm{~N}_{2}$ by ${ }^{14} \mathrm{~N}_{2}$ is not likely to be a reaction that is important to catalytic reduction of dinitrogen, but its mechanism turns out to be noteworthy. The conversion of Mo ${ }^{15} \mathrm{~N}_{2}$ to $\mathbf{M o}^{14} \mathrm{~N}_{2}$ under ${ }^{14} \mathrm{~N}_{2}$ is readily followed by IR, either by following the decrease of the $\nu_{15 \mathrm{~N} 15 \mathrm{~N}}$ absorption in $\mathbf{M o}^{15} \mathrm{~N}_{2}$ or the increase of the $\nu_{14 \mathrm{~N} 14 \mathrm{~N}}$ absorption in $\mathbf{M o}^{14} \mathrm{~N}_{2}$ (Scheme 1). In $\mathrm{C}_{6} \mathrm{D}_{6}$ the reaction was reported to be first order in Mo and slow, with $t_{1 / 2}$ $\approx 35 \mathrm{~h}$ at $1 \mathrm{~atm}$ and $22^{\circ} \mathrm{C}(16)$. The exchange reaction also was followed in heptane at (total) pressures of 30 psi (15 psi overpressure) where $t_{1 / 2}=32 \mathrm{~h}$, and $55 \mathrm{psi}$ (40 psi overpressure) where $t_{1 / 2}=$ $30 \mathrm{~h}$. These results suggest that the exchange of ${ }^{15} \mathrm{~N}_{2}$ for ${ }^{14} \mathrm{~N}_{2}$ is independent of dinitrogen pressure up to 55 psi, with $k_{\text {obs }}=6 \times$ $10^{-6} \mathrm{~s}^{-1}$. Therefore, dinitrogen exchange (Scheme 1) apparently is dissociative with the naked species (14; Fig. 2), or possibly some weakly "solvated" variation thereof, the likely intermediate. A bisdinitrogen intermediate, $\mathbf{M o}\left(\mathrm{N}_{2}\right)_{2}$, must be a relatively highenergy species, in contrast to the $\mathbf{M o}\left(\mathrm{N}_{2}\right)(\mathrm{L})$ intermediates noted above. The reason why replacement of ${ }^{15} \mathrm{~N}_{2}$ with ${ }^{14} \mathrm{~N}_{2}$ cannot be bimolecular in the simplest terms is that only three frontier orbitals are readily available in the coordination pocket, and an intermediate or transition state that contains two dinitrogens would require

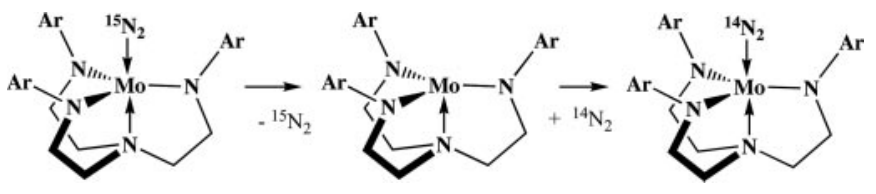

Scheme 1.

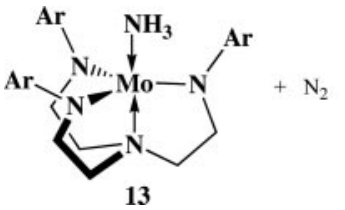
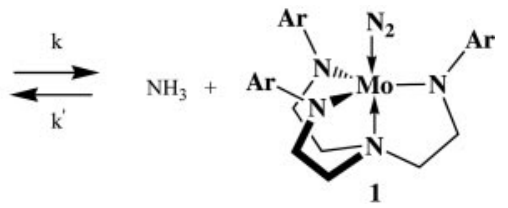

Scheme 2.

that at least four orbitals be used $(2 \sigma$ and $2 \pi)$. On the other hand, replacement of dinitrogen by a simple $\sigma$ bonding ligand, or vice versa, requires only three orbitals.

It is interesting to note that exchange of ${ }^{15} \mathrm{~N}_{2}$ in $\left[\mathrm{HTBTN}_{3} \mathrm{~N}\right] \mathrm{Mo}^{15} \mathrm{~N}_{2}$ (where HTBT is hexa-t-butylterphenyl) under ${ }^{14} \mathrm{~N}_{2}$ is exceedingly slow in $\mathrm{C}_{6} \mathrm{D}_{6}$ (weeks) (20). The consumption of $\left[\mathrm{HTBTN}_{3} \mathrm{~N}\right] \mathrm{Mo}^{15} \mathrm{~N}_{2}$ was followed by IR and shown to be transformed into [HTBTN $\left.{ }_{3} \mathrm{~N}\right] \mathrm{Mo}^{14} \mathrm{~N}_{2}$ in a reaction that is first order in $\left[\mathrm{HTBTN}_{3} \mathrm{~N}\right] \mathrm{Mo}^{15} \mathrm{~N}_{2}$ with $k=2.6 \times 10^{-7} \mathrm{~s}^{-1}$ at $22^{\circ} \mathrm{C}\left(t_{1 / 2} \sim 750 \mathrm{~h}\right)$. At $5 \mathrm{~atm}$ overpressure of ${ }^{14} \mathrm{~N}_{2}$ the result was essentially the same $\left(k=3.1 \times 10^{-7} \mathrm{~s}^{-1}\right)$. Because $\nu_{\mathrm{NN}}=1,990 \mathrm{~cm}^{-1}$ in $\left[\mathrm{HTBTN}_{3} \mathrm{~N}\right] \mathrm{Mo}^{14} \mathrm{~N}_{2}$, the same as in $\mathrm{Mo}^{14} \mathrm{~N}_{2}$, the Mo- $\mathrm{N}_{2}$ bond strength in $\left[\mathrm{HTBTN}{ }_{3} \mathrm{~N}\right] \mathrm{Mo}^{14} \mathrm{~N}_{2}$ must be similar to that in $\mathbf{M o}^{14} \mathrm{~N}_{2}$. The only explanation for a rate of unimolecular exchange that is $\approx 20$ times slower than in $\mathbf{M o}^{15} \mathrm{~N}_{2}$ appears to be that ${ }^{15} \mathrm{~N}_{2}$ cannot escape the binding cavity in $\left[\mathrm{HTBTN}{ }_{3} \mathrm{~N}\right] \mathrm{Mo}^{15} \mathrm{~N}_{2}$ as readily as it does in $\mathbf{M o}^{15} \mathrm{~N}_{2}$, and free ${ }^{14} \mathrm{~N}_{2}$ and free ${ }^{15} \mathrm{~N}_{2}$ cannot be within the cavity above the metal simultaneously. Other evidence suggests that the degree of steric crowding in $\left[\mathrm{HTBTN}_{3} \mathrm{~N}\right] \mathrm{Mo}$ compounds is so severe as to limit reactions required for reduction of dinitrogen (see below).

The reaction between $\mathbf{M o N}_{2}$ and ammonia (under dinitrogen) leads within 1-2 $\mathrm{h}$ to an equilibrium mixture of $\mathbf{M o N} \mathrm{N}_{2}$ and $\mathbf{M o}\left(\mathrm{NH}_{3}\right)$ (Scheme 2). For example ammonia ( $0.28 \mathrm{~atm}, \approx 21$ equiv vs. Mo) was added to $\mathrm{MoN}_{2}$ in $\mathrm{C}_{6} \mathrm{D}_{6}$ under dinitrogen. The solubility of ${ }^{15} \mathrm{~N}_{2}$ at $22^{\circ} \mathrm{C}$ in $\mathrm{C}_{6} \mathrm{D}_{6}$ was measured vs. an internal ${ }^{15} \mathrm{~N}$ standard $\left(\mathrm{CH}_{3}{ }^{15} \mathrm{NO}_{2}\right)$, whereas the solubility of ammonia was measured by proton NMR (as described in the supporting information).

In $\mathrm{C}_{6} \mathrm{D}_{6}$ the solubility of ammonia was found to be $0.1 \mathrm{M} \mathrm{atm}^{-1}$, and the solubility of ${ }^{15} \mathrm{~N}_{2}$ was found to be $0.04 \mathrm{M} \mathrm{atm}^{-1}$. If we assume that there is no significant difference between the solubility of ${ }^{15} \mathrm{~N}_{2}$ and ${ }^{14} \mathrm{~N}_{2}$, then $K_{\text {eq }}\left(\left[\mathrm{MoN}_{2}\right]\left[\mathrm{NH}_{3}\right] /\left[\mathrm{Mo}\left(\mathrm{NH}_{3}\right)\right]\left[\mathrm{N}_{2}\right]\right)$ can be determined readily. In a series of experiments of this type, $K_{\text {eq }}$ was established to be $\approx 0.1$ (see supporting information for details). The fact that equilibrium is reached in 1-2 $\mathrm{h}$ rules out any rate-limiting unimolecular loss of dinitrogen from $\mathbf{M o N}_{2}$; dinitrogen most likely is replaced by ammonia in a bimolecular reaction. Because the reaction between $\mathrm{Mo}\left(\mathrm{NH}_{3}\right)$ and dinitrogen must pass through the same intermediate or transition state as the reaction between $\mathbf{M o N}_{2}$ and ammonia, the reaction between $\mathrm{Mo}\left(\mathrm{NH}_{3}\right)$ and dinitrogen must depend on dinitrogen pressure (this hypothesis is the case; see below). Second, the reaction between $\mathbf{M o}\left(\mathrm{NH}_{3}\right)$ and dinitrogen is related to that between other $\mathbf{M o}(\mathrm{L})$ species and dinitrogen noted above (where L is THF or 2,6-Lut), which are complete within seconds at $1 \mathrm{~atm}$ of dinitrogen. We assume that reactions that involve these other Mo(L) species are also first order in dinitrogen, but confirmation has been difficult for experimental reasons; the exchange is simply too fast using current techniques. Clearly, ammonia is much more strongly bound than THF or 2,6-Lut to Mo, as one might expect on the basis of their relative Brønsted basicities $\left(\mathrm{NH}_{3}>2,6-\mathrm{Lut}>\mathrm{THF}\right)$.

Reduction of $\left\{\mathbf{M o}\left(\mathrm{NH}_{3}\right)\right\}^{+}$by $\mathrm{CrCp}_{2}^{*}$ in heptane or CoCp $\mathrm{C}_{2}^{*}$ in THF is complete within seconds. Therefore, $\mathbf{M o}\left(\mathrm{NH}_{3}\right)$ can be prepared and studied in situ. We are particularly interested in the rate of the forward reaction in Scheme 2. When we follow the conversion by taking aliquots from a vial for IR spectra and plot $\ln \left(1-A / A_{\infty}\right)$ vs. time (where $A$ is the absorbance for the $\mathbf{M o N}_{2}$ that is formed), we obtain a nearly straight line through two half-lives 
Table 2. Data for conversion of $\mathrm{Mo}(\mathrm{III})\left(\mathrm{NH}_{3}\right)$ to $\mathrm{Mo}(\mathrm{III})\left(\mathrm{N}_{2}\right)$ complexes (by IR unless otherwise noted)

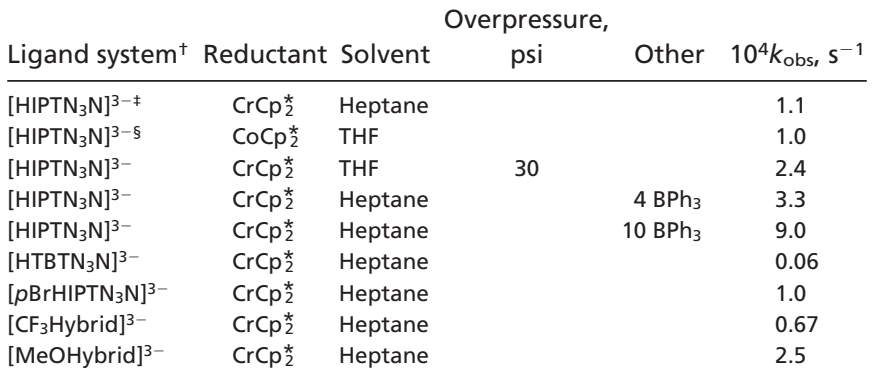

${ }^{\dagger} \mathrm{BAr}_{4}^{\prime}$ salt unless otherwise noted.

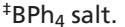

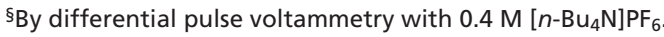

from which an observed first-order rate constant of $\approx 1 \times 10^{-4} \mathrm{~s}^{-1}$ can be obtained. This experiment has been repeated several times (Table 2). The reaction also was followed by differential pulse voltammetry in THF (Table 2) in an open vial in the drybox; the rate of disappearance of the wave ascribed to the $\left\{\mathbf{M o}\left(\mathrm{NH}_{3}\right)\right\}^{+/ 0}$ couple at $-1.63 \mathrm{~V}$ vs. an internal ferrocene/ferrocenium standard was found to be first order in Mo, and the observed rate constant was found to be $1.0 \times 10^{-4} \mathrm{~s}^{-1}$. When this exchange was followed by IR at an overpressure of $15 \mathrm{psi}, k_{\mathrm{obs}}$ was found to be $2.4 \times 10^{-4}$ $\mathrm{s}^{-1}$. The exchange clearly depends upon dinitrogen pressure, i.e., dinitrogen concentration in solution.

The conversion of $\mathbf{M o}\left(\mathrm{NH}_{3}\right)$ to $\mathbf{M o N} \mathrm{N}_{2}$ actually is not a simple reaction. A typical starting concentration of $\mathbf{M o}\left(\mathrm{NH}_{3}\right)$ might be 0.02 $\mathrm{M}$, so that at $t_{1 / 2}$ the ammonia concentration $(0.01 \mathrm{M}$ if none leaves the solution) is much greater than what it would be at equilibrium. Therefore, ammonia back-reacts with $\mathrm{MoN}_{2}$ to yield $\mathrm{Mo}\left(\mathrm{NH}_{3}\right)$ many times before it diffuses out of benzene on a time scale of 1-2 $\mathrm{h}$. (We know that equilibrium is not established for $1-2 \mathrm{~h}$ from the equilibrium studies discussed above.) Therefore, the apparent rate constant found in the bulk experiments is much less than what it would be if the ammonia were somehow completely removed as it formed. We also can calculate that if conversion of $\mathrm{Mo}\left(\mathrm{NH}_{3}\right)$ to $\mathrm{MoN}_{2}$ is observed in a closed vial or other small vessel, the equilibrium amount of $\mathbf{M o}\left(\mathrm{NH}_{3}\right)$ remaining is not negligible, with the exact amount of course depending on the headspace in the closed vessel. How much ammonia is lost entirely will then depend on how often the vessel is opened and for how long, etc. In most runs in fact the plot or $\ln \left(1-A / A_{\infty}\right)$ vs. time is curved toward the "end" of the run, consistent with an approach to an equilibrium and/or an incorrect value for $A_{\infty}$. We also find that results vary with conditions, e.g., solvent volume, as one might expect.

Two pieces of evidence suggest that $k_{\text {obs }}$ for conversion of $\mathbf{M o}\left(\mathrm{NH}_{3}\right)$ to $\mathbf{M o N}_{2}$ is actually $\approx 10$ times what it appears to be in "bulk" conversions. First, in a CV in which $\left\{\mathbf{M o}\left(\mathrm{NH}_{3}\right)\right\}^{+}$is first reduced to $\mathrm{Mo}\left(\mathrm{NH}_{3}\right)$, the reversible reduction of $\mathbf{M o N} \mathrm{N}_{2}$ to $\left\{\mathbf{M o N}_{2}\right\}^{-}$can be observed at slow $\left(10 \mathrm{mV} \cdot \mathrm{s}^{-1}\right)$ scan rates (17), consistent with replacement of a significant amount of ammonia in $\operatorname{Mo}\left(\mathrm{NH}_{3}\right)($ say, $\approx 5 \%)$ with dinitrogen shortly after $\mathrm{Mo}\left(\mathrm{NH}_{3}\right)$ is formed ( $30 \mathrm{~s}$ to $1 \mathrm{~min})$. These estimated values suggest that $k_{\mathrm{obs}}$ for conversion of $\mathrm{Mo}\left(\mathrm{NH}_{3}\right)$ to $\mathrm{MoN}_{2}$ is in fact $\approx 10^{-3} \mathrm{~s}^{-1}$, with the half-life between 10 and $15 \mathrm{~min}$. One could argue that in this $\mathrm{CV}$ experiment the tiny amount of ammonia in the diffusion layer near the electrode migrates into the bulk solution in which there is no ammonia rapidly enough so that a significant amount of $\mathbf{M o N}_{2}$ in fact can be observed at the electrode surface during the $\mathrm{CV}$ experiment.

The second piece of evidence is that conversion of $\mathrm{Mo}\left(\mathrm{NH}_{3}\right)$ to $\mathrm{MoN}_{2}$ is accelerated dramatically in the presence of $\mathrm{BPh}_{3}$. These reactions all show strictly linear plots of $\ln \left(1-A / A_{\infty}\right)$ vs. time and reach a maximum $k_{\text {obs }}$ in the presence of $\approx 15$ equiv of $\mathrm{BPh}_{3}$ that is again $\approx 10^{-3} \mathrm{~s}^{-1}$ (see Table 2 and supporting information). The ammonia adduct of $\mathrm{BPh}_{3}$ was shown not to react with $\mathrm{MoN}_{2}$, and $\mathrm{BPh}_{3}$ was shown not to react with $\mathrm{Mo}\left(\mathrm{NH}_{3}\right)$ in the absence of dinitrogen at room temperature over a period of hours. Therefore, we conclude that conversion of $\mathrm{Mo}\left(\mathrm{NH}_{3}\right)$ into $\mathbf{M o N} \mathrm{N}_{2}$ is accelerated because free ammonia is scavenged by $\mathrm{BPh}_{3}$. The "saturation" value for $k_{\mathrm{obs}}$ for this reaction $\left(10^{-3} \mathrm{~s}^{-1}\right)$ is consistent with the rough estimate obtained in the CV experiment described above. If we assume that the true $k_{\text {obs }}$ is $10^{-3} \mathrm{~s}^{-1}$ and the concentration of dinitrogen in solution is $0.04 \mathrm{M}$, then the true bimolecular rate constant ( $k$ in Scheme 2) becomes $2.5 \times 10^{-2} \mathrm{M}^{-1} \cdot \mathrm{s}^{-1}$, and $k^{\prime}$ becomes $0.25 \mathrm{M}^{-1} \cdot \mathrm{s}^{-1}$. Therefore, although conversion of $\mathrm{Mo}\left(\mathrm{NH}_{3}\right)$ into $\mathrm{MoN}_{2}$ should be complete in $<1 \mathrm{~h}$, the back-reaction between ammonia and $\mathbf{M o N} \mathrm{N}_{2}$ to reform $\mathbf{M o}\left(\mathrm{NH}_{3}\right)$ slows the rate of conversion of $\mathrm{Mo}\left(\mathrm{NH}_{3}\right)$ to $\mathrm{MoN}_{2}$ by $\approx 1$ order of magnitude. It is interesting to note that the estimated rate constant for displacement of THF from Mo(THF) by dinitrogen to give $\mathbf{M o N}_{2}\left(25 \mathrm{M}^{-1} \cdot \mathrm{s}^{-1}\right.$; see above) is $10^{3}$ times larger than that for conversion of $\mathbf{M o}\left(\mathrm{NH}_{3}\right)$ into $\mathrm{MoN}_{2}\left(0.025 \mathrm{M}^{-1} \cdot \mathrm{s}^{-1}\right)$, largely because ammonia is simply a much better $\mathrm{s}$ base than THF.

What We Know About the Catalytic Conversion of Dinitrogen to Ammonia. Dinitrogen is reduced catalytically in heptane with [2,6lutidinium] $\mathrm{BAr}_{4}^{\prime}$ [where $\mathrm{Ar}^{\prime}$ is $3,5-\left(\mathrm{CF}_{3}\right)_{2} \mathrm{C}_{6} \mathrm{H}_{3}$ ] as the proton source and decamethylchromocene as the electron source in the presence of several of the isolated complexes shown in Fig. 2 under the conditions described in 2003 (14). A total of 7-8 equiv of ammonia are formed out of $\approx 12$ possible (depending on the Mo derivative used), which suggests an efficiency of $\approx 65 \%$ based on the reducing equiv available, with the efficiency of formation of ammonia from gaseous dinitrogen being 55-60\%. A run employing Mo${ }^{15} \mathrm{~N}={ }^{15} \mathrm{NH}$ under ${ }^{15} \mathrm{~N}_{2}$ yielded entirely ${ }^{15} \mathrm{~N}$-labeled ammonia. $\mathrm{CoCp}_{2}$, which is a weaker reducing agent than $\mathrm{CrCp}_{2}^{*}$ by $140 \mathrm{mV}$ in $\mathrm{THF}$ and $300 \mathrm{mV}$ in PhF (Table 1), also can be used as the reducing agent for catalytic dinitrogen reduction, although it is approximately half as efficient as $\mathrm{CrCp}_{2}^{*}(17)$.

An important question is the following: What product or products are formed besides ammonia? One possibility is hydrazine. We analyzed one run under standard conditions for hydrazine, as described in the supporting information. The amount of hydrazine formed was $<0.01$ equiv vs. the catalyst. This result contrasts with the only other known catalytic reduction of dinitrogen by Mo, where the major product is hydrazine (10 parts for each ammonia) (13).

A second likely possibility is that dihydrogen is formed. We find that dihydrogen is in fact formed, and the amount is that predicted if all remaining reducing equiv go into forming dihydrogen. A typical result is a $64 \%$ yield of ammonia (on the basis of electrons available) and a 33\% yield of dihydrogen. Therefore, we believe that only ammonia and dihydrogen are formed under standard conditions (see supporting information).

If the Mo catalyst is left out of a standard run, we can examine the production of hydrogen in a "background" reaction. Several runs in heptane and one in THF all show that the yield of dihydrogen produced upon adding $\mathrm{CrCp}_{2}^{*}$ to [2,6-lutidinium] $\mathrm{BAr}_{4}^{\prime}$ is only $\approx 60 \%$ of that expected in a period of $6 \mathrm{~h}$. In contrast, if [2,4,6-trimethylpyridinium] $\mathrm{BAr}_{4}^{\prime}$ (collidinium) is used as the acid source, then $>95 \%$ of the expected hydrogen is obtained. Although we have not yet identified the initial reduction product, preliminary NMR evidence suggests that after workup of the 2,6-lutidinium reduction in air, the product is the bipyridine formed through coupling in the para position of 2,6-Lut. This bipyridine can be prepared through reduction of 2,6-Lut with sodium followed by treatment of the reaction with $\mathrm{SO}_{2}(21)$. However, the electron balance for production of dihydrogen and ammonia in catalytic runs suggest that this bipyridine is not formed to any significant extent under catalytic conditions. Relatively slow coupling of 2,4,6- 
Table 3. Variation of the ammonia yield with the nature of the acid (BAr's salt)

\begin{tabular}{llccc} 
Other & \multicolumn{1}{c}{$\mathrm{BH}^{+}$} & $\begin{array}{c}\text { Total } \mathrm{NH}_{3,} \\
\text { equiv }\end{array}$ & $\begin{array}{c}\% \text { vs. } \\
\text { theory }\end{array}$ & $\begin{array}{c}\% \text { from } \\
\mathrm{N}_{2}\end{array}$ \\
\hline & $2,4,6-\mathrm{Me}_{3} \mathrm{C}_{6} \mathrm{H}_{2} \mathrm{NH}^{+}$ & $7.2 / 12$ & 60 & 52 \\
& $2,4-\mathrm{Me}_{2} \mathrm{C}_{6} \mathrm{H}_{3} \mathrm{NH}^{+}$ & $5.1 / 12$ & 42 & 34 \\
& $2,6-\mathrm{Et}_{2} \mathrm{C}_{6} \mathrm{H}_{3} \mathrm{NH}^{+}$ & $3.7 / 12$ & 31 & 23 \\
& $2,6-\mathrm{Ph}_{2} \mathrm{C}_{6} \mathrm{H}_{3} \mathrm{NH}^{+}$ & $0.4 / 6$ & 7 & 0 \\
+145 2,6-Lut & $3,5-\mathrm{Me}_{2} \mathrm{C}_{6} \mathrm{H}_{3} \mathrm{NH}^{+}$ & $1.0 / 12$ & 9 & 0 \\
$+150 \mathrm{THF}$ & $2,6-\mathrm{Me}_{2} \mathrm{C}_{6} \mathrm{H}_{3} \mathrm{NH}^{+}$ & $1.5 / 6$ & 25 & 8 \\
& $2,6-\mathrm{Me}_{2} \mathrm{C}_{6} \mathrm{H}_{3} \mathrm{NH}^{+}$ & $2.7 / 6$ & 45 & 28 \\
& $\mathrm{Et}_{3} \mathrm{NH}^{+}$ & $0.7 / 12$ & 6 & 0 \\
\hline
\end{tabular}

collidinium can account for the near quantitative yield of hydrogen noted above. A similar 4,4' coupling upon reduction of $N$-alkylated 2,6-lutidinium salts has been known for some time (22-24).

The yield of ammonia depends dramatically on the nature of the acid used, as shown in Table 3. Use of [2,4,6-collidinium]BAr ${ }_{4}^{\prime}$ yields results analogous to those obtained in runs that employ [2,6lutidinium]BAr'. However, other pyridinium salts yield less to no ammonia. [2,6-diphenylpyridinium] $\mathrm{BAr}_{4}^{\prime}$ and [3,5-dimethylpyridinium]BAr' in fact produce no ammonia from dinitrogen. In Table 3, we also show that addition of a large amount of 2,6-Lut or THF to a standard reaction both significantly reduce the yield of ammonia. We believe that the pyridinium salt and pyridine that build up as acid is consumed play several complex roles that cannot be deconvoluted at this stage. Finally, we have shown that $\left[\mathrm{Et}_{3} \mathrm{NH}\right] \mathrm{BAr}_{4}^{\prime}$ is not a successful acid; no ammonia is produced from dinitrogen in a standard catalytic reaction.

In Table 4, we show how the yield of ammonia depends on the rate of addition of the reducing agent and the pressure. (Only the ammonia yield was measured in these runs.) Addition of all of the reducing agent in $30 \mathrm{~s}$ followed by stirring the reaction for $6 \mathrm{~h}$ leads to a dramatically reduced yield of ammonia from dinitrogen $(24 \%)$. Increasing the pressure to 30 psi leads to a small but measurable increase in the yield of ammonia, $71 \%$ vs. $63 \%$ for a 6 -h addition and $55 \%$ vs. $45 \%$ for a 3 -h addition time. The pressure dependence of ammonia formation is consistent with an increase in the amount of $\mathrm{Mo}\left(\mathrm{NH}_{3}\right)$ converted to $\mathbf{M o N} \mathrm{N}_{2}$ at higher pressures and therefore a greater yield of ammonia. An interesting question is whether the efficiency of conversion of dinitrogen into ammonia can be pushed beyond $75 \%$ (1 equiv of dihydrogen per dinitrogen reduced) at several atmospheres $\mathrm{N}_{2}$ pressure.

It occurred to us that the yield of ammonia might depend on the volume above the reaction solution if ammonia diffuses out of solution into that volume relatively quickly during the catalytic reaction and again allows more $\mathbf{M o}\left(\mathrm{NH}_{3}\right)$ to be converted into $\mathbf{M o N}_{2}$. We now know this hypothesis to not be the case when the volume is increased from 68 to $330 \mathrm{ml}$ (see supporting information). Ammonia produced during catalysis is not efficiently converted to ammonium salts by excess lutidinium, because when a standard reaction is pumped to dryness, the amount of ammonia in the volatiles was found to be 6.3 equiv out of a typical total of 7.5 obtained when the dry residue is also worked up. Therefore, $\approx 80 \%$

Table 4. The yield of ammonia depends on the rate of addition of the reducing agent and the pressure

\begin{tabular}{llcrc} 
Pressure, psi & Catalyst & Add time & Yield, equiv & \% from $\mathrm{N}_{2}$ \\
\hline 15 & $\mathrm{MoN}_{2}$ & $6 \mathrm{~h}$ & $7.6 / 12$ & 63 \\
15 & $\mathrm{Mo} \equiv \mathrm{N}$ & $3 \mathrm{~h}$ & $5.4 / 12$ & 45 \\
15 & $\mathrm{MoN}_{2}$ & $30 \mathrm{~s}$ & $2.83 / 12$ & 24 \\
30 & $\mathrm{MoN}_{2}$ & $6 \mathrm{~h}$ & $8.55 / 12$ & 71 \\
30 & $\mathrm{Mo} \equiv \mathrm{N}$ & $3 \mathrm{~h}$ & $6.58 / 12$ & 55 \\
\hline
\end{tabular}

Table 5. The yield of ammonia (out of a possible 12 equiv) in a standard reaction using organometallic compounds as catalysts

\begin{tabular}{lcc} 
Mo compound & $\mathrm{NH}_{3}$, equiv & $\%$ from $\mathrm{N}_{2}$ \\
\hline$\left[\mathrm{HIPTN}{ }_{3} \mathrm{~N}\right] \mathrm{Mo}\left(\eta^{2}-\mathrm{C}_{2} \mathrm{H}_{4}\right)$ & 2.6 & 22 \\
{$\left[\mathrm{HIPTN}{ }_{3} \mathrm{~N}\right] \mathrm{Mo}\left(\eta^{2}-\mathrm{C}_{2} \mathrm{H}_{2}\right)$} & 2.3 & 19 \\
{$\left[\mathrm{HIPTN}_{3} \mathrm{~N}\right] \mathrm{MoMe}$} & 3.5 & 29 \\
{$\left[\mathrm{HIPTN}_{3} \mathrm{~N}\right] \mathrm{MoEt}$} & $4.9,5.1$ & 42 \\
{$\left[\mathrm{HIPTN}{ }_{3} \mathrm{~N}\right] \mathrm{Mo}(n-$ hexyl) } & 6.3 & 53 \\
{$\left[\mathrm{HIPTN}{ }_{3} \mathrm{~N}\right] \mathrm{Mo}(n-\mathrm{octyl})$} & $6.0,6.4$ & 52 \\
{$\left[\mathrm{HIPTN}{ }_{3} \mathrm{~N}\right] \mathrm{Mo} \equiv \mathrm{CH}$} & 1.8 & 15 \\
{$\left[\mathrm{HIPTN}{ }_{3} \mathrm{~N}\right] \mathrm{Mo} \equiv \mathrm{CMe}$} & 4.7 & 39 \\
\hline
\end{tabular}

of the product is present as ammonia (rather than ammonium) in the headspace and solution, with diffusion of ammonia out of solution and throughout the entire "headspace" being incomplete, relatively slow, or both. In a typical catalytic run, the final solution volume is $\approx 10 \mathrm{ml}$ and the headspace is $68 \mathrm{ml}$. If we assume that 8 equiv of ammonia are formed, that the ammonia in solution is in equilibrium with that in the gas phase, and that no ammonium salt forms, then the amount of ammonia in the gas phase is calculated to be $\approx 75 \%$ of the total formed.

To study the longevity of the catalytic reaction, "sequential" catalytic runs were carried out. After the first standard run, the ammonia that was generated and all volatiles (solvent and 2,6-Lut) were removed in vacuo. The solid residue (a mixture of all Mospecies, $\left[\mathrm{NH}_{4}\right] \mathrm{BAr}_{4}^{\prime},\left[\mathrm{CrCp}_{2}^{*}\right] \mathrm{BAr}_{4}^{\prime}$, and possible products of decomposition such as free ligand) was then reloaded with another 48 equiv of [2,6-LutH]BAr' and treated with 36 equiv of $\mathrm{CrCp}_{2}^{*}$ as in a normal run. Typically, 6.3 equiv of ammonia are found in the first stage, as noted above, and 1.7 equiv of ammonia in the second stage, for a total of 8.0 equiv. In some standard runs, the total ammonia plus ammonium has totaled 8.0 equiv. Therefore, little or no ammonia appears to be formed in the second stage of a sequential or "double" catalytic run. Use of 2,4,6-pyridinium as the acid source does not alter this result.

We have found that $\mathrm{MoH}$ is as competent (65-66\% efficiency in electrons) as any other molybdenum species that we have used; apparently at least 1 equiv of dihydrogen is produced under catalytic conditions from $\mathbf{M o H}$ (20). Catalytic reactions that employ organometallic derivatives as "precatalysts" also yield ammonia from dinitrogen under standard conditions (Table 5). The most successful are the $n$-hexyl or $n$-octyl complexes, which in fact are as successful as $\mathbf{M o H}$. One can imagine that $\mathrm{MoR}$ is protonated to yield $\mathrm{RH}$ and $\mathrm{MoN}_{2}$ in the presence of reducing agent and dinitrogen (Scheme 3). It is curious that the long chain alkyl complexes are more successful than the shorter-chain ethyl and especially methyl derivatives. The reasons are not yet known.

Characteristics of $\mathbf{M o}-\mathbf{N}=\mathbf{N H}$. Mo- $\mathrm{N}=\mathrm{NH}$ (3 in Fig. 2) has been prepared through protonation of $\{\mathbf{M o}-\mathrm{N}=\mathrm{N}\}^{-}$with $\left[\mathrm{Et}_{3} \mathrm{NH}\right] \mathrm{BAr}_{4}^{\prime}$ and has been characterized structurally $(16,17)$. Although the proton on the $\beta$ nitrogen atom could not be located in the x-ray study, ${ }^{15} \mathrm{~N}$ and proton NMR studies have established conclusively that a proton is present on $\mathrm{N}_{\beta}\left(\mathrm{J}_{\mathrm{HN} \beta}=54 \mathrm{~Hz}, \mathrm{~J}_{\mathrm{HN} \alpha}=8 \mathrm{~Hz}\right)$. Upon heating Mo-N $=\mathrm{NH}$ in benzene, it slowly decomposes to $\mathbf{M o H}$ and dinitrogen in a slow first-order " $\beta$-elimination" process $(k=2.2 \times$ $10^{-6} \cdot \mathrm{s}^{-1}, t_{1 / 2}=90 \mathrm{~h}$ at $61^{\circ} \mathrm{C}$ ) (16). Decomposition of $\mathrm{Mo}-\mathrm{N}=\mathrm{NH}$ is a problem even at room temperature over the long term, a

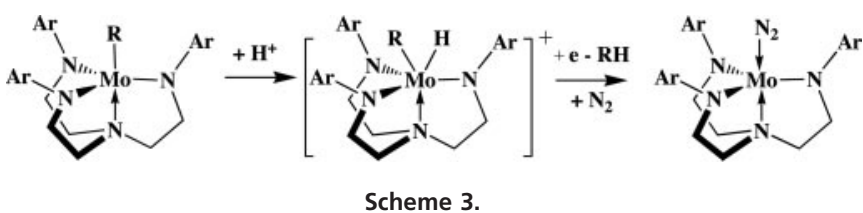




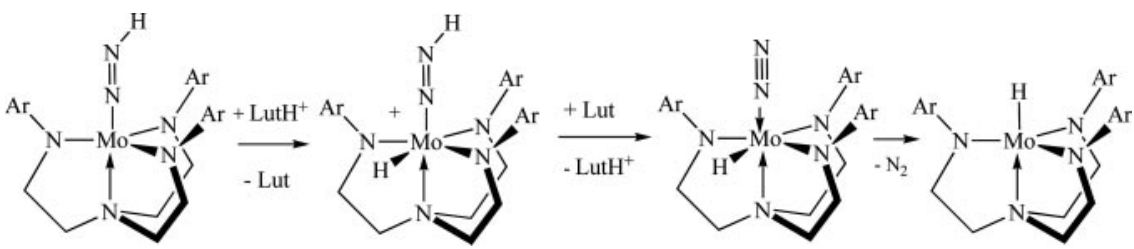

Scheme 4.

circumstance that complicated obtaining crystals suitable for an x-ray study (17). Decomposition to $\mathrm{MoH}$ is accelerated 1 order of magnitude in the presence of $1 \%\left[\mathrm{Et}_{3} \mathrm{NH}\right] \mathrm{OTf}$ or $\left[\mathrm{Et}_{3} \mathrm{NH}\right] \mathrm{BAr}_{4}^{\prime}$ to give $\mathrm{MoH}$ and dinitrogen (16). A logical proposal is that the metal itself is protonated, and a proton is then lost from the diazenido ligand to generate $\mathrm{Mo}(\mathrm{H})\left(\mathrm{N}_{2}\right)$, which then rapidly loses dinitrogen to leave $\mathrm{MoH}$ (Scheme 4). In the presence of $\left[\mathrm{H}\left(\mathrm{Et}_{2} \mathrm{O}\right)_{2}\right] \mathrm{BAr}_{4}^{\prime}$, $\mathrm{Mo}-\mathrm{N}=\mathrm{NH}$ is protonated at $\mathrm{N}_{\beta}$ to yield $\left[\mathrm{Mo}=\mathrm{NNH}_{2}\right]^{+}$, but $[2,6-\mathrm{LutH}] \mathrm{BAr}_{4}^{\prime}$ only partially and reversibly protonates Mo$\mathrm{N}=\mathrm{NH}$ at $\mathrm{N}_{\beta}$. The $\mathrm{pK}_{\mathrm{a}}$ of $\mathrm{MoN}=\mathrm{NH}$ appears to be approximately the same as that of $\mathrm{DBUH}^{+}$in THF $\left[\mathrm{pK}_{\mathrm{a}}=16.6\right.$ vs. 12.5 for $\mathrm{Et}_{3} \mathrm{~N}$ (25)], because $\mathrm{MoN}=\mathrm{NH}$ can be deprotonated to a considerable degree by DBU (1,8-diaza-bicyclo-[5.4.0]-undec-7-ene) in THF (17). It should be noted that the reaction between $\{\text { Mo-N }=N\}^{-}$ and $[2,6-\mathrm{LutH}] \mathrm{BAr}_{4}^{\prime}$ gave largely $\mathbf{M o N}_{2}$, not $\mathbf{M o}-\mathrm{N}=\mathrm{NH}$. The relative rates of acid-catalyzed decomposition to $\mathrm{MoH}$ vs. protonation at $\mathrm{N}_{\beta}$ and further reduction are not known.

Alternatives to the [HIPTN $\left.{ }_{3} \mathbf{N}\right]^{3-}$ Ligand. Three "symmetric" variations of the $\left[\mathrm{HIPTN}_{3} \mathrm{~N}\right]^{3-}$ ligand have been explored (20), a hexa-t-butylterphenyl (HTBT)-substituted $\left(\left[\mathrm{HTBTN}_{3} \mathrm{~N}\right]^{3-}\right)$ ligand, a hexamethylterphenyl-substituted $\left(\left[\mathrm{HMTN}_{3} \mathrm{~N}\right]^{3-}\right)$ ligand, and a $\left[p \mathrm{BrHIPTN}_{3} \mathrm{~N}\right]^{3-}$ ligand in which the para position of the central phenyl ring is substituted with a bromide. IR and electrochemical studies suggest that complexes that contain $\left[\mathrm{HTBTN}_{3} \mathrm{~N}\right]^{3-}$ are slightly more electron rich than those that contain the parent $\left[\mathrm{HIPTN}_{3} \mathrm{~N}\right]^{3-}$ ligand, whereas those that contain $\left[p \mathrm{BrHIPTN}_{3} \mathrm{~N}\right]^{3-}$ are slightly more electron poor (20). An x-ray study of $\left[\mathrm{HTBTN}{ }_{3} \mathrm{~N}\right] \mathrm{MoCl}$ shows that $\left[\mathrm{HTBTN}_{3} \mathrm{~N}\right] \mathrm{Mo}$ complexes are significantly more crowded sterically than Mo complexes. $\left[\mathrm{HMTN}_{3} \mathrm{~N}\right] \mathrm{Mo}$ complexes are likely to be significantly less crowded than Mo complexes, and $\left[p \mathrm{BrHIPTN}_{3} \mathrm{~N}\right]$ Mo complexes are likely to have approximately the same steric crowding as Mo complexes. In practice, transformations of $\left[\mathrm{HTBTN}_{3} \mathrm{~N}\right]^{3-}$ derivatives that involve electron and proton transfer (e.g., conversion of [HTBTN $\left.{ }_{3} \mathrm{~N}\right] \mathrm{MoN}_{2}$ into $\left[\mathrm{HTBTN}_{3} \mathrm{~N}\right] \mathrm{Mo}-\mathrm{N}=\mathrm{NH}$ ) are slower by perhaps an order of magnitude compared with analogous conversions of $\left[\mathrm{HIPTN}_{3} \mathrm{~N}\right]^{3-}$ derivatives (20), consistent with a high degree of steric crowding.

$\left[p \mathrm{BrHIPTN}_{3} \mathrm{~N}\right] \mathrm{Mo}^{\circ} \mathrm{N}$ was found to be a good catalyst for the formation of ammonia, with yields only slightly less than those observed employing $\left[\mathrm{HIPTN}_{3} \mathrm{~N}\right]^{3-}$ derivatives $(\approx 65 \%)$. On the other hand, $\left[\mathrm{HMBTN}{ }_{3} \mathrm{~N}\right] \mathrm{Mo} \equiv \mathrm{N}$ was found to be a poor catalyst for the reduction of dinitrogen, with only 1.06 equiv of ammonia being observed. Therefore, only 0.06 equiv are formed from gaseous dinitrogen.

We measured the rates of conversion of the ammonia complex with the dinitrogen complex in the $\left[p \mathrm{BrHIPTN}_{3} \mathrm{~N}\right]^{3-}$ and $\left[\mathrm{HTBTN}_{3} \mathrm{~N}\right]^{3-}$ systems (Table 2). Conversion of $\left[p \mathrm{BrHIPTN} \mathrm{H}_{3} \mathrm{~N}\right] \mathrm{Mo}\left(\mathrm{NH}_{3}\right)$ into $\left[p \mathrm{BrHIPTN}_{3} \mathrm{~N}\right] \mathrm{MoN}_{2}$ under $1 \mathrm{~atm}$ of dinitrogen in heptane at $22^{\circ} \mathrm{C}$ showed that the half-life for formation of $\left[p \mathrm{BrHIPTN}_{3} \mathrm{~N}\right] \mathrm{MoN}_{2}$ is $\approx 2 \mathrm{~h}$, the same as for conversion of $\mathbf{M o}\left(\mathrm{NH}_{3}\right)$ into $\mathrm{MoN}_{2}$. On the other hand, the half-life for conversion of $\left[\mathrm{HTBTN} \mathrm{H}_{3} \mathrm{~N}\right]\left(\mathrm{NH}_{3}\right)$ into $\left[\mathrm{HTBTN}_{3} \mathrm{~N}\right] \mathrm{MoN}_{2}$ under conditions analogous to those used for $\mathrm{Mo}\left(\mathrm{NH}_{3}\right)$ was found to be $\approx 30 \mathrm{~h}$. This finding is further evidence that the $\left[\mathrm{HTBTN}{ }_{3} \mathrm{~N}\right]^{3-}$ system is simply too crowded for what we presume at this stage to be a bimolecular displacement of ammonia by dinitrogen. This problem coupled with the observable (slower) reduction of $\left\{\left[\mathrm{HTBTN} \mathrm{H}_{3} \mathrm{~N}\right] \mathrm{Mo}\left(\mathrm{NH}_{3}\right)\right\}^{+}$to $\left[\mathrm{HTBTN}_{3} \mathrm{~N}\right] \mathrm{Mo}\left(\mathrm{NH}_{3}\right)$ makes any catalytic reduction of dinitrogen unlikely to be able to compete with "direct" reduction of 2,6-lutidinium to yield dihydrogen.

$\left[\mathrm{HMBTN} \mathrm{N}_{3} \mathrm{~N}\right] \mathrm{Mo} \equiv \mathrm{N}$ as a catalyst under standard conditions was also relatively unsuccessful; only 0.47 equiv of ammonia were formed from dinitrogen. One possible problem is the low solubility of $\left[\mathrm{HMBTN}_{3} \mathrm{~N}\right] \mathrm{Mo} \equiv \mathrm{N}$, and probably other intermediates (in heptane). However, there may be other problems related to those found for hybrid alternatives below.

It is possible to make the minimum change in a $\left[\mathrm{HIPTN}_{3} \mathrm{~N}\right]^{3-}$ ligand, i.e., to reduce the size of the substituent on only one of the arms, as shown in Fig. 5 (W.W.W., R.R.S., A. Hock, and P.M., unpublished results). When these three $\left[\left(\mathrm{HIPTNCH} \mathrm{CH}_{2}\right)_{2} \mathrm{NCH}_{2} \mathrm{CH}_{2} \mathrm{~N}-3,5-\mathrm{R}_{2} \mathrm{C}_{6} \mathrm{H}_{3}\right] \mathrm{Mo} \equiv \mathrm{N}$ ([RHybrid $]^{3-}$ ) species are used in a standard attempted catalytic reaction, no ammonia is produced from dinitrogen using any of them (W.W.W., R.R.S., A. Hock, and P.M., unpublished results). The $\left[\mathrm{CF}_{3} \text { Hybrid }\right]^{3-}$ derivative was chosen to study in more detail.

The half-life for conversion of $\left[\mathrm{CF}_{3} \mathrm{Hybrid}\right] \mathrm{Mo}\left(\mathrm{NH}_{3}\right)$ into $\left[\mathrm{CF}_{3}\right.$ Hybrid $] \mathrm{MoN}_{2}$ was shown to be $\approx 170$ min, which we do not feel is significantly longer than the half-life for conversion of $\mathbf{M o}\left(\mathrm{NH}_{3}\right)$ into $\mathbf{M o N}_{2}(\approx 120 \mathrm{~min})$ to result in failure of the catalytic reaction in the $\left[\mathrm{CF}_{3} \mathrm{Hybrid}\right]^{3-}$ system. Therefore, reduction must fail in the $\left[\mathrm{CF}_{3} \mathrm{Hybrid}\right]^{3-}$ system for some reason other than a slow conversion of the ammonia complex into the nitrogen complex.

$\left[\mathrm{CF}_{3}\right.$ Hybrid] $\mathrm{Mo}-\mathrm{N}=\mathrm{NH}$ can be prepared by treating $\left\{\left[\mathrm{CF}_{3}\right.\right.$ Hybrid $\left.] \mathrm{MoN}_{2}\right\} \mathrm{Na}(\mathrm{THF})_{2}$ with $\mathrm{H}\left(\mathrm{OEt}_{2}\right)_{2} \mathrm{BAr}_{4}^{\prime}$ (0.95 equiv; Scheme 5). It has not been possible to isolate $\left[\mathrm{CF}_{3} \mathrm{Hybrid}\right] \mathrm{Mo}-$ $\mathrm{N}=\mathrm{NH}$, as a consequence of its extreme solubility and instability. Proton NMR spectra revealed a $\mathrm{Mo}-\mathrm{N}=\mathrm{N} H$ resonance at $8.6 \mathrm{ppm}$; in the ${ }^{15} \mathrm{~N}$-labeled compound, $\mathrm{J}_{\mathrm{N} \beta \mathrm{H}}=54.5 \mathrm{~Hz}$ and $\mathrm{J}_{\mathrm{N} \alpha \mathrm{H}}=8 \mathrm{~Hz}$, close to those for the previously characterized Mo-N $=\mathrm{NH}$ species (15). When prepared in benzene- $\mathrm{d}_{6},\left[\mathrm{CF}_{3}\right.$ Hybrid $] \mathrm{Mo}-\mathrm{N}=\mathrm{NH}$ has been observed to decompose to $\left[\mathrm{CF}_{3} \mathrm{Hybrid}\right] \mathrm{MoN}_{2}$ at a rate that is first order in Mo with a rate constant of $6.6 \pm 0.7 \times 10^{-4} \mathrm{~min}^{-1}$ $\left(t_{1 / 2}=17 \pm 2 \mathrm{~h}\right)$. If we compare this rate with the decomposition of $\mathrm{Mo}-\mathrm{N}=\mathrm{NH}$, two differences are readily apparent. First, Mo$\mathrm{N}=\mathrm{NH}$ decomposes to $\mathrm{MoH}$, whereas $\left[\mathrm{CF}_{3} \mathrm{Hybrid}\right] \mathrm{Mo}-\mathrm{N}=\mathrm{NH}$ decomposes to $\left[\mathrm{CF}_{3} \mathrm{Hybrid}\right] \mathrm{MoN}_{2}$. Second, the rate of decomposition of $\left[\mathrm{CF}_{3}\right.$ Hybrid $] \mathrm{Mo}-\mathrm{N}=\mathrm{NH}$ is significantly faster than that of Mo- $\mathrm{N}=\mathrm{NH}$, which decomposes at a rate where $k=1.3 \times 10^{-4}$ $\min ^{-1}\left(t_{1 / 2}=92 \mathrm{~h}\right)$ at $61^{\circ} \mathrm{C}$. It may be important to recognize that

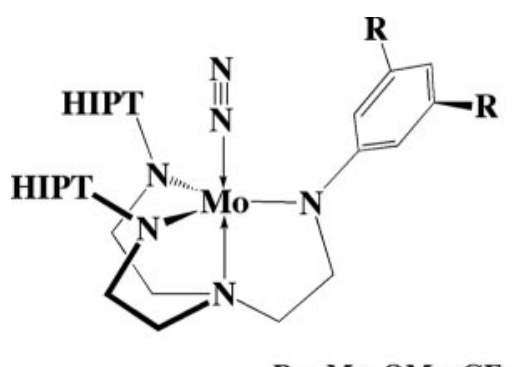

$\mathrm{R}=\mathrm{Me}, \mathrm{OMe}, \mathrm{CF}_{3}$

Fig. 5. Drawing of a [RHybrid] $\mathrm{MoN}_{2}$ complex. 

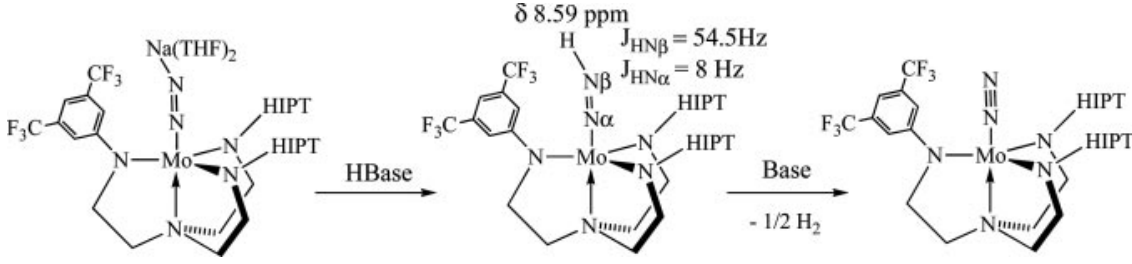

Scheme 5 .

$\left[\mathrm{CF}_{3}\right.$ Hybrid $] \mathrm{Mo}-\mathrm{N}=\mathrm{NH}$ is prepared in situ, so the product or products of any side reaction (e.g., free ligand) are present. On the basis of the results explained below, the decomposition that we observed therefore may be catalyzed by some side product.

Labeling studies are informative. $\left[\mathrm{CF}_{3} \mathrm{Hybrid}\right] \mathrm{Mo}-\mathrm{N}=\mathrm{ND}$ was found to decompose to $\left[\mathrm{CF}_{3} \mathrm{Hybrid}\right] \mathrm{MoN}_{2}$ with $k_{\mathrm{H}} / k_{\mathrm{D}}=3.9$; therefore, a N-H(D) bond must be cleaved during the rate-limiting step. An interesting observation was made while observing the decomposition of $\left[\mathrm{CF}_{3} \mathrm{Hybrid}\right] \mathrm{Mo}-{ }^{15} \mathrm{~N}={ }^{15} \mathrm{NH}$ under ${ }^{14} \mathrm{~N}_{2}$; $\left[\mathrm{CF}_{3}\right.$ Hybrid $] \mathrm{Mo}-{ }^{15} \mathrm{~N}={ }^{15} \mathrm{NH}$ was converted into $\left[\mathrm{CF}_{3} \mathrm{Hybrid}\right] \mathrm{Mo}-$ ${ }^{14} \mathrm{~N}={ }^{14} \mathrm{NH}$ at a rate that was first order in Mo and with $k=2.6 \times$ $10^{-2} \min ^{-1}\left(t_{1 / 2}=4.5 \mathrm{~h}\right)$. We have reexamined $\mathbf{M o}-{ }^{15} \mathrm{~N}={ }^{15} \mathrm{NH}$ under similar conditions and found that it also undergoes this exchange reaction, but at a rate at least 100 times slower than that of $\left[\mathrm{CF}_{3} \mathrm{Hybrid}\right] \mathrm{Mo}-\mathrm{N}=\mathrm{NH}$. Whether this difference in ${ }^{15} \mathrm{~N}$ exchange rate is important for understanding why catalytic reduction of dinitrogen fails in the $\left[\mathrm{CF}_{3} \mathrm{Hybrid}\right]^{3-}$ system is not yet known.

In an attempt to use catalytically relevant proton sources, [2,6-lutidinium]BAr' was used to form $\left[\mathrm{CF}_{3} \mathrm{Hybrid}\right] \mathrm{Mo}-\mathrm{N}=\mathrm{NH}$ in situ. The rate of decomposition of $\left[\mathrm{CF}_{3} \mathrm{Hybrid}\right] \mathrm{Mo}-\mathrm{N}=\mathrm{NH}$ was found to be $1.05 \times 10^{-2} \mathrm{~min}^{-1}\left(t_{1 / 2}=1.1 \mathrm{~h}\right)$. Use of $\left[\mathrm{Et}_{3} \mathrm{NH}\right] \mathrm{BAr}_{4}^{\prime}$ as the proton source resulted in a $t_{1 / 2}$ of $<5 \mathrm{~min}$; only trace amounts of $\left[\mathrm{CF}_{3} \mathrm{Hybrid}\right] \mathrm{Mo}-\mathrm{N}=\mathrm{NH}$ were observed $10 \mathrm{~min}$ after addition. To confirm that the conjugate base is accelerating the decomposition of $\left[\mathrm{CF}_{3} \mathrm{Hybrid}\right] \mathrm{Mo}-\mathrm{N}=\mathrm{NH}, 4$ equiv of 2,6-Lut, 2,4,6-collidine, or $\mathrm{Et}_{3} \mathrm{~N}$ was added to samples of $\left[\mathrm{CF}_{3} \mathrm{Hybrid}\right] \mathrm{Mo}-\mathrm{N}=\mathrm{NH}$ synthesized by using $\mathrm{H}\left(\mathrm{OEt}_{2}\right)_{2} \mathrm{BAr}_{4}^{\prime}$. In all three cases, all $\left[\mathrm{CF}_{3} \mathrm{Hybrid}\right] \mathrm{Mo}-\mathrm{N}=\mathrm{NH}$ decomposed within 5 min to $\left[\mathrm{CF}_{3}\right.$ Hybrid] $\mathrm{MoN}_{2}$.

On the basis of these experiments, we conclude that the less sterically encumbered hybrid systems fail to reduce dinitrogen catalytically as a consequence of a base-catalyzed shunt at the $\mathrm{Mo}-\mathrm{N}=\mathrm{NH}$ point in the catalytic cycle that yields dihydrogen (Fig. 6). Because we typically use the nitride as the precatalyst for our catalytic runs, at least 4 equiv of base are present when $\mathrm{Mo}-\mathrm{N}=\mathrm{NH}$ is synthesized in catalytic reactions, which is sufficient to reduce the half-life of $\left[\mathrm{CF}_{3} \mathrm{Hybrid}\right] \mathrm{Mo}-\mathrm{N}=\mathrm{NH}$ to $<5 \mathrm{~min}$. Interestingly, when $\left[\mathrm{CF}_{3} \mathrm{Hybrid}\right] \mathrm{MoN}_{2}$ is used as the precatalyst, 0.7 equiv of $\mathrm{NH}_{3}$ are produced, indicating that the $\left[\mathrm{CF}_{3} \mathrm{Hybrid}\right] \mathrm{Mo}-\mathrm{N}=\mathrm{NH}$ step can be (partially) traversed under catalytic conditions when only $\approx 1$ equiv of base is present.

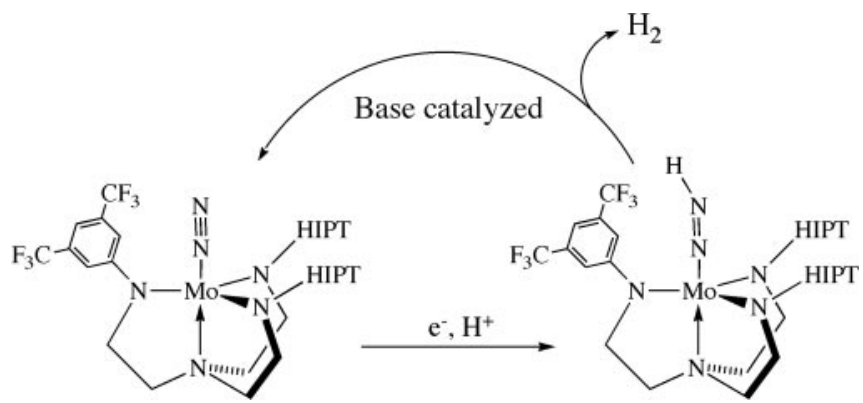

Fig. 6. A shunt that limits dinitrogen reduction in the less sterically crowded $\left[\right.$ RHybrid ${ }^{3-}$ systems.

\section{Conclusions}

We have shown that conversion of a Mo(III) ammonia complex $\left(\mathrm{Mo}\left(\mathrm{NH}_{3}\right)\right)$ into a $\mathrm{Mo}(\mathrm{III})$ dinitrogen complex $\left(\mathrm{MoN}_{2}\right)$ involves displacement of ammonia by dinitrogen with $k$ estimated to be $2.5 \times 10^{-2} \mathrm{M}^{-1} \cdot \mathrm{s}^{-1}$ and $K_{\text {eq }}$ estimated to be 0.1 at room temperature. Therefore, $\mathbf{M o}\left(\mathrm{NH}_{3}\right)$ should be converted into $\mathrm{MoN}_{2}$ relatively quickly (a half-life of $\approx 15 \mathrm{~min}$ at $1 \mathrm{~atm}$ ), but conversion is slowed by $\approx 1$ order of magnitude as a consequence of ammonia not being removed efficiently. In contrast, the rate of displacement (it is assumed) of the weaker Brønsted base from Mo(THF) to give $\mathbf{M o N}_{2}$ is $10^{3}$ times larger. A slower displacement of ammonia by dinitrogen is shown not to be the reason why several catalytic reactions by complexes that contain hybrid ligands fail. Finally, we have found that bimolecular displacement of dinitrogen by a $\sigma$ bonding ligand, or vice versa, is relatively fast, because three orbitals are available in the transition state, whereas bimolecular displacement of dinitrogen for dinitrogen is slow because four orbitals are required.

We believe the main reason that catalytic reduction of dinitrogen fails for the hybrid systems to be that the Mo-N $=\mathrm{NH}$ species is decomposed before it can be protonated at the $\beta$ nitrogen atom (as in $\mathbf{3} \rightarrow \mathbf{4}$ in Fig. 2). It is striking that instability of the $\mathrm{Mo}-\mathrm{N}=\mathrm{NH}$ species is the consequence when only one of the three substituents on the amido nitrogens is a "small" 3,5-disubstituted phenyl group. In this situation, there is slightly less steric hindrance, either between the "arms" of the triamidoamine ligand and/or above the apical pocket where the diazenido ligand is located. The most surprising finding is that a base (including 2,6-Lut, the conjugate base of the acid used in a standard reduction) catalyzes decomposition of the Mo- $\mathrm{N}=\mathrm{NH}$ species in the sterically less crowded hybrid species to yield $\mathrm{MoN}_{2}$ and dihydrogen. The rate-limiting step of the lutidine-catalyzed decomposition of Mo-N $=\mathrm{NH}$ is unimolecular in Mo and appears to involve cleavage of the $\beta \mathrm{NH}$ bond. The precise nature of this apparent base-induced decomposition is unknown at this time.

It clearly will be important to prepare complexes that contain other hybrid ligands that resemble the parent $\left[\mathrm{HIPTN}{ }_{3} \mathrm{~N}\right]^{3-}$ ligand system more and more closely. We suspect that the stability of various $\mathrm{Mo}-\mathrm{N}=\mathrm{NH}$ species toward 2,6-Lut will correlate with the success of the catalytic reduction of dinitrogen. We also must examine the stability of the parent Mo$\mathrm{N}=\mathrm{NH}$ species under a variety of conditions, including its stability toward the conjugate bases of the acids shown in Table 3. Nevertheless, it is premature to conclude that failure of any given catalytic reaction can be ascribed to instability of its $\mathrm{Mo}-\mathrm{N}=\mathrm{NH}$ intermediate. In any scheme as complex as that shown in Fig. 2, there are many opportunities for failure.

\section{Experimental Methods}

All MoX compounds, other than [Mo(THF)][BAr' $\left.{ }_{4}^{\prime}\right]$, have been reported (14-16). [Mo(THF)][BAr $\left.{ }_{4}^{\prime}\right]$ was synthesized by oxidation of $\mathbf{M o N}_{2}$ as described in supporting information. Mo(alkyl) compounds were synthesized as reported $(16,26)$. [Hybrid]MoX compounds were synthesized in a similar manner to the corre- 
sponding MoX system $(15,16)$. Diazenido compounds (Mo$\mathrm{N}=\mathrm{NH}$ and $\left[\mathrm{CF}_{3} \mathrm{Hybrid}\right] \mathrm{Mo}-\mathrm{N}=\mathrm{NH}$ ) were synthesized in situ as described in supporting information.

Electrochemical studies were performed similarly to those reported $(11,16)$. Catalytic experiments were performed as reported (14). Variations of this procedure are described in supporting information.

$\mathbf{M o N H}_{3}$ and $\mathbf{M o N} \mathrm{N}_{2}$ exchange studies were performed as described in the supporting information. IR spectroscopy was used to quantify the formation of $\mathrm{MoN}_{2}$.

1. Burgess BK, Lowe DJ (1996) Chem Rev 96:2983.

2. Hardy RWF, Bottomley F, Burns RC (1979) A Treatise on Dinitrogen Fixation (Wiley Interscience, New York).

3. Veeger C, Newton WE (1984) Advances in Nitrogen Fixation Research (Dr W Junk/Martinus Nijhoff, Boston).

4. Coughlan MP, ed (1980) Molybdenum and Molybdenum-Containing Enzymes (Pergamon, New York).

5. Eady RR (1996) Chem Rev 96:3013-3030.

6. Smith BE (1999) Adv Inorg Chem 47:159-218.

7. Rehder D (1999) Coord Chem Rev 182:297-322.

8. Rees DC, Howard JB (2000) Curr Opin Chem Biol 4:559-566.

9. Bolin JT, Ronco AE, Morgan TV, Mortenson LE, Xuong LE (1993) Proc Natl Acad Sci USA 90:1078-1082.

10. Kim J, Rees DC (1992) Science 257:1677-1682.

11. Einsle O, Tezcan FA, Andrade SLA, Schmid B, Yoshida M, Howard JB, Rees DC (2002) Science 297:1696-1700.

12. Seefeldt LC, Dance IG, Dean DR (2004) Biochemistry 43:1401-1409.

13. Shilov AE (2003) Russ Chem Bull Int Ed 52:2555-2562.

14. Yandulov DV, Schrock RR (2003) Science 301:76-78.
Hydrogen quantification was performed with a 6890C GC (Hewlett-Packard, Palo Alto, CA) fitted with a $30-\mathrm{m} / 0.5-\mathrm{mm} /$ 25-mm molecular sieve column and a TCD. Briefly, $50 \mathrm{ml}$ of gas was extracted from the experimental system and injected into the GC. The results were compared with a calibration curve to determine the amount of $\mathrm{H}_{2}$ present.

Structural and experimental details and other data are provided in supporting information.

R.R.S. was supported by National Institutes of Health Grant GM 31978.

15. Yandulov DV, Schrock RR (2002) J Am Chem Soc 124:6252-6253.

16. Yandulov DV, Schrock RR, Rheingold AL, Ceccarelli C, Davis WM (2003) Inorg Chem 42:796-813.

17. Yandulov D, Schrock RR (2005) Inorg Chem 44:1103-1117.

18. Humphries MJ, Tellmann KP, Gibson VC, White AJP, Williams DJ (2005) Organometallics 24:2039-2050.

19. Greco GE, O’Donoghue MB, Seidel SW, Davis WM, Schrock RR (2000) Organometallics 19:1132-1149.

20. Ritleng V, Yandulov DV, Weare WW, Schrock RR, Hock AR, Davis WM (2004) J Am Chem Soc 126:6150-6163.

21. Hünig S, Wehner I (1989) Synthesis 1989:552-554.

22. Kosower EM (1983) Topics Curr Chem 112:117-162.

23. Carelli I, Cardinali ME, Casini A, Arnone A (1976) J Org Chem 41:3967-3969.

24. Oturan MA (1988) J Electroanal Chem 242:171-179.

25. Rodima T, Kaljurand I, Pihl A, Mäemets V, Leito I, Koppel IA (2002) J Org Chem 67:1873-1881.

26. Byrnes MJ, Dai X, Schrock RR, Hock AS, Müller P (2005) Inorg Chem 24: 4437-4450. 